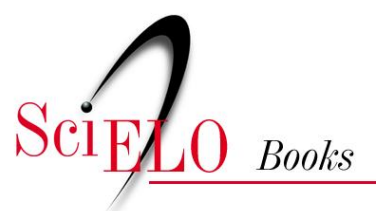

\title{
II. O partido abolicionista
}

\author{
Joaquim Nabuco
}

\section{SciELO Books / SciELO Livros / SciELO Libros}

NABUCO, J. O partido abolicionista. In: $O$ abolicionismo [online]. Rio de Janeiro: Centro Edelstein de Pesquisas Sociais, 2011. O partido abolicionista. pp. 8-12. ISBN: 978-85-7982-070-0. https://doi.org/10.7476/9788579820700.0003.

\section{() povour}

This work is free of known copyright restrictions. http://creativecommons.org/publicdomain/mark/1.0/

Este trabalho está livre de restrições de direito de autor e/ou de direitos conexos conhecidas.

http://creativecommons.org/publicdomain/mark/1.0/

Esta obra está libre de restricciones conocidas de derechos autorales. http://creativecommons.org/publicdomain/mark/1.0/ 


\section{O PARTIDO ABOLICIONISTA}

Não há maior honra para um partido do que sofrer pela sustentação de princípios que ele julga serem justos.

W.E. Gladstone

O sentido em que é geralmente empregada a expressão partido abolicionista não corresponde ao que, de ordinário, se entende pela palavra partido. A esse respeito algumas explicações são necessárias.

Não há dúvida de que já existe um núcleo de pessoas identificadas com o movimento abolicionista, que sentem dificuldade em continuar filiadas nos partidos existentes, por causa das suas ideias. Sob a bandeira da abolição, combatem hoje liberais, conservadores, republicanos, sem outro compromisso - e este tácito e por assim dizer de honra política - senão o de subordinarem a rejeição partidária a outra maior, à consciência humana. Assim como, na passada legislatura, diversos liberais julgaram dever votar pela ideia abolicionista de preferência a votar pelo seu partido, também nas seguintes encontrar-se-ão conservadores prontos a fazer outro tanto e republicanos que prefiram combater pela causa da liberdade pessoal dos escravos a combater pela forma de governo da sua aspiração.

A simples subordinação do interesse de qualquer dos atuais partidos ao interesse da emancipação basta para mostrar que o partido abolicionista, quando surgir, há de satisfazer um ideal de pátria mais elevado, compreensivo e humano, do que o de qualquer dos outros partidos já formados, os quais são todos mais ou menos sustentados e bafejados pela escravidão. Não se pode todavia, por enquanto, chamar partido à corrente de opinião, ainda não encaminhada para seu destino, a cuja expansão assistimos.

Entende-se por partido não uma opinião somente, mas uma opinião organizada para chegar aos seus fins: o abolicionismo é por hora, uma agitação, e é cedo ainda para se dizer se será algum dia um partido. Nós o vemos desagregando fortemente os partidos existentes, e até certo ponto constituindo uma igreja à parte composta dos cismáticos de todas as outras. No Partido Liberal a corrente conseguiu, pelo menos, pôr a descoberto os alicerces mentirosos do liberalismo entre nós. Quanto ao Partido Conservador, devemos esperar a prova da passagem pelo poder que desmoralizou os seus adversários, para sabermos que ação o abolicionismo exercerá sobre ele. Uma nova dissidência, com a mesma bandeira de 1871, valeria um exército para a nossa causa. Restam os republicanos.

$\mathrm{O}$ abolicionismo afetou esse partido de um modo profundo, e a nenhum fez tanto bem. Foi a lei de 28 de setembro e a ideia, adrede espalhada entre os fazendeiros, de que o imperador era o chefe do movimento contra a escravidão, que de repente engrossou as fileiras republicanas com uma leva de voluntários saídos de onde menos se imaginava. A República compreendeu a oportunidade dourada que se lhe oferecia, e não a desprezou; o partido, não falo da opinião, mas da associação, aproveitou largamente as simpatias que lhe procurava a corajosa defesa, empreendida notavelmente pelo Sr. Cristiano Ottoni, dos interesses da grande propriedade. Como era natural, por outro lado, o abolicionismo, depois de muitas hesitações, impôs-se ao espírito de grande número de republicanos como uma obrigação maior, mais urgente, mais justa, e a todos os respeitos mais considerável, do que a de mudar a forma do governo com o auxílio de proprietários de homens. Foi na forte democracia escravagista de São Paulo que a contradição desses dois estados sociais se manifestou de modo mais evidente.

Supondo que a República seja a forma natural da democracia, ainda assim, o dever de elevar os escravos a homens precede a toda arquitetura democrática. O abolicionismo num país de escravos é para o republicano de razão a República oportunista, a que pede o que pode conseguir e o que mais precisa, e não se esteriliza em querer antecipar uma ordem de coisas da qual o país só pode tirar benefícios reais quando nele não houver mais senhores. Por outro lado, a teoria inventada para contornar a dificuldade sem a resolver, de que pertence à Monarquia acabar com a escravidão, e que o Partido Republicano nada tem com isso, lançou, para muitos que se haviam alistado nas fileiras da República, um clarão sinistro sobre a aliança contraída em 1871.

É, com efeito, difícil hoje a um liberal ou conservador, convencido dos princípios cardeais do desenvolvimento social moderno e do direito inato - no estado de civilização - de cada homem à sua liberdade pessoal, e deve sê-lo muito mais para um republicano, fazer parte homogênea de 
organizações em cujo credo a mesma natureza humana pode servir para base da democracia e da escravidão, conferir a um indivíduo, ao mesmo tempo, o direito de tomar parte no governo do país e o de manter outros indivíduos - porque os comprou ou os herdou - em abjeta subserviência forçada, durante toda a vida. Conservadores constitucionais; liberais que se indignam contra o governo pessoal, republicanos, que consideram degradante o governo monárquico da Inglaterra e da Bélgica, exercitando dentro das porteiras das suas fazendas, sobre centena de entes rebaixados da dignidade de pessoa, poder maior que o de um chefe africano nos seus domínios, sem nenhuma lei escrita que o regule, nenhuma opinião que o fiscalize, discricionário, suspeitoso, irresponsável: que mais é preciso para qualificar, segundo uma frase conhecida, essa audácia com que os nossos partidos assumem os grandes nomes que usam - de estelionato político?

É por isso que o abolicionismo desagrega dessas organizações os que as procuram por causa daqueles nomes históricos, segundo as suas convicções individuais. Todos os três partidos baseiam as sua aspirações políticas sobre um estado social cujo nivelamento não os afeta; o abolicionismo, pelo contrário, começa pelo princípio, e, antes de discutir qual o melhor modo para um povo ser livre de governar-se a si mesmo - é essa a questão que divide os outros -, trata de tornar livre a esse povo, aterrando o imenso abismo que separa as duas castas sociais em que ele se extrema.

Nesse sentido, o abolicionismo deveria ser a escola primária de todos os partidos, o alfabeto da nossa política, e não o é; por um curioso anacronismo, houve um partido republicano muito anos antes de existir uma opinião abolicionista, e daí a principal razão porque essa política é uma Babel na qual ninguém se entende. Qual será, porém, o resultado da desagregação inevitável? Irão os abolicionistas, separados, pela sinceridade das suas ideias de partidos, que têm apenas interesses e ambições pessoais como razão de ser, e os princípios somente por pretexto, agrupando-se lentamente num partido comum, a princípio unidos pela proscrição social que estão sofrendo, e depois pela esperança de vitória? Haverá um partido abolicionista organizado, com a intuição completa da sua missão no presente e no futuro, para presidir à transformação do Brasil escravo no Brasil livre, e liquidar a herança da escravidão?

Assim aconteceu nos Estados Unidos, onde o atual Partido Republicano, ao surgir na cena política, teve que dominar a rebelião, emancipar quatro milhões de escravos, estabelecer definitivamente o novo regime de liberdade e da igualdade em Estados que queriam formar, nas praias do golfo do México, a maior potência escravocrata do mundo. É natural que isso aconteça no Brasil; mas é possível também que - em vez de fundir-se num só partido por causa das grandes divergências internas entre liberais, conservadores e republicanos - o abolicionismo venha trabalhar os três partidos de forma a cindi-los sempre que seja preciso - como o foi em 1871 para a passagem da lei Rio Branco - reunir os elementos progressistas de cada um numa cooperação desinteressada e transitória, numa aliança política limitada a certo fim; ou que venha mesmo a decompor, e reconstituir diversamente os partidos existentes, sem, todavia, formar um partido único e homogêneo.

O advento do abolicionismo coincidiu com a eleição direta, e sobretudo com a aparição de uma força, a qual se está solidificando em torno da imprensa - cuja barateza e distribuição por todas as classes é um fator importante na história da democratização do país -, força que é a opinião pública. Todos esses elementos devem ser tomados em consideração quando se quer saber como o abolicionismo há de, por fim, constituir-se.

Neste livro, entretanto, a expressão partido abolicionista significará tão somente, o movimento abolicionista, a corrente de opinião que se está desenvolvendo do Norte ao Sul. É claro que há no grupo de pessoas que têm manifestado vontade de aderir àquele movimento mais do que o embrião de um partido. Caso amanhã, por qualquer circunstância, se organizasse um gabinete abolicionista, se o que constitui um partido são pretendentes a posições ou honras políticas, aspirantes a lugares remunerados, clientes de ministros, caudatários do governo - aquele núcleo sólido teria uma cauda adventícia tão grande pelo menos como a dos partidos oficiais.

Basta considerar que, quanto mais se fracionam esses partidos no governo, mais lhes cresce o séquito. O poder é infelizmente entre nós - e esse é um dos efeitos mais incontestáveis do servilismo que a escravidão deixa após si - a região gerações espontâneas. Qualquer ramo, por mais murcho e seco, deixado numa noite ao alento desta atmosfera privilegiada, aparece na manhã seguinte coberto de folhas. Não há como negar o influxo desse fiat: é toda a nossa história. "O Poder é o Poder" foi uma frase que resumiu a sabedoria da experiência de todos os nossos homens públicos, e sobre a qual assentam todos os seus cálculos. Nenhuma opinião remotamente 
distante do governo pode ostentar o pessoal numeroso dos dois partidos que se alternam no exercício do patronado e na guarda do cofre das graças, distribuem empresas e favores, e por isso têm em torno de si, ou às suas ordens e sob seu mando - num país que a escravidão empobreceu e carcomeu -, todos os elementos dependentes e necessitados da população. Isso mesmo caracteriza a diferença entre o abolicionismo e os dois partidos constitucionais: o poder destes é, praticamente, o poder da escravidão toda, como instituição privada e como instituição política; o daquele é o poder tão somente das forças que começam a rebelar-se contra semelhante monopólio - da terra, do capital e do trabalho - que faz da escravidão um estado no Estado, cem vezes mais forte do que a própria nação. 